\title{
TEACHING ALPAHBET FOR NON NATIVE ENGLISH LEARNERS: A CASE STUDY OF FIRST GRADERS
}

\author{
Agnes Widyaningrum ${ }^{1}$, Vinna Octavia ${ }^{2}$ \\ Faculty of Language and Culture Studies Stikubank University \\ e-mail: 1agneswidyaningrum@edu.unisbank.ac.id, 2vinnaoctva@gmail.com
}

\begin{abstract}
Non-native English learners need time to learn English language since they just heard without knowing how to pronounce it correctly. This condition occurs in common Primary Schools because the students do not have foreign language background, at school as well as at home. The hidden curriculum focusing on students' soft skills are not well administered as the school managements think that what they have to do in running the academic atmosphere is teaching well for their students. The first step in teaching English for young learners especially those who are non-native English learners is introducing English by getting to know it. Piaget's child's development contributes in helping teachers to know their student's growth physically and mentally in order to help them learn better while they play different teacher's roles. Piaget proves that cognitivism gives insight that is children's develop through stages since they were born. First graders at their age is on the stage called preoperational with one of characteristics that is language development with the goal to create symbolic thought. One way to achieve this goal is by teaching alphabet for first graders.
\end{abstract}

Keywords: Piaget's child development, first graders, teaching alphabet

\section{INTRODUCTION}

First graders of primary schools in Indonesia mostly do not have English lesson as one of school subject's that they have to learn. This condition is in accordance with government's regulation that gives opportunities for schools to have English lesson as one of the school's subject. It is due to the school's capability and resources because the real condition of each school may differ one to another therefore the role of English for first graders is not a must thing to do for common primary school in Indonesia.

School is a place for students to learn something in order to get knowledge to improve their competence and performance and teachers are important element to deliver knowledge to their students. The role of teachers as well as educators are not an easy thing to do especially for the first graders. The first graders, at the age of 6-7 years old are still in their growth stage to develop their physical as well as mental. Based on Jean Piaget's theory about child's development is that the elementary students are in their stage of preoperational to concrete operations (Shaffer, David 
R \& Kipp, Katherine, 2010: 55). The shift between these two stages occurred naturally for normal students.

For first graders, their school time is limited as they are categorized as early year students of elementary school so that they have a few school subjects only. The teaching and learning process is done with fun activities aimed at building students' motivation to schooling. Psychologically, the first graders are still immature in their thinking process because they move from their sensorimotor (birth to 2 years) with major development namely begin to internalize behavioral schemes to produce images or mental scheme to the preoperational stage (2 to 7 years) with the development that is beginning to recognize that other people may not always perceive the world as they do (Piaget's Stages of Cognitive Development). Those two stages have their own characteristics, from the sensorimotor stage, children are capable of complex sensorimotor coordination and preoperational stage, children use symbolism (images and language) to represent and understand various aspects of the environment (Shaffer, David R \& Kipp, Katherine, 2010: $55)$.

Piaget's stages is known as child cognitive development because he focuses his study on what children know and tell nothing about how they think (intelligence). In order to help young learners know something (objects), the teachers will use various strategies for examples, in teaching numbers or colours, the teachers will bring something (teaching aids like toys and coloring chart) to help their students can visualize what they have seen and internalize it into their brain and when they have known about it they will learn to name the object. At first, they use their five senses to learn but on the next step they will be able to use their memory and create symbolic thoughts.

This study is conducted in order to answer one problem due to English lesson for primary students namely: How do teachers teach English for first graders who are non-native English learners? The role of teacher nowadays is as the facilitator therefore in each classroom there are two teachers who teach and help students to get knowledge to develop their competence and performance using Piaget's stage of cognitive development. There is a preliminary study conducted focusing on applying cooperative learning in teaching English vocabulary (Vinna et al, 2019) and this study proposes another insight to help teachers to teach alphabet for first graders. 


\section{RESEARCH METHOD}

This study belongs to descriptive study because it is aimed at describing how teaching alphabet is done in order to teach first graders of non-native English learners learn English for their first time. The case study is chosen as this study is conducted in one of State Elementary Schools in Semarang. The number of students involved in this study is 56 students and there are two classes which are involved namely 1A (28 students) and 1B (28 students). There are two teachers involved with the help of researcher's team to conduct this study.

The composition of first graders are: 1 A class with 28 students consists of 12 female and 16 male and 1B with 28 students consists of 13 female and 15 male students. The gender differences also matter as written by Opal Dunn an educational consultant and author (https://learnenglishkids.britishcouncil.org/helping-your-child/how-young-children-learnenglish-another-language) wrote that Boys' brains develop differently from girls' and this affects how boys pick up language and use it. It means that young girls have more natural ability in using language than boys. Some cases may result that boys have difficulty in using language because their brains developed differently concerning to language development. This idea is supported with Piaget's invariant developmental sequences that is all children progress through the stages in exactly the order in which they are listed.

The case study is the nature of this study because the researchers try to emphasize contextual analysis of a limited conditions and their relationship. According to Robert K Yin (1984:23) case study is an empirical enquiry that investigates a contemporary phenomenon within its real life context when the boundaries within the phenomenon and context are not clearly evident and which multiple sources of evidence are used (https://www.ischool.utexas.edu/ ssoy/usesusers/1391d1b.htm). The researchers in this study chose one state elementary school with 56 students to be investigated with the case that is teaching alphabet in the school for first graders who study there, they are non-native English learners whom never learnt English formally before.

This study is conducted with the purpose to find out the strategies in teaching alphabet for first graders as non-native English learners in various ways. The teaching alphabet is conducted for 10 times with the following schedules:

$1^{\text {st }}$ meeting : : Introduction by giving Pre Test 
$2^{\text {nd }}$ to $3^{\text {rd }}$ meeting $\quad:$ Teaching alphabet

$4^{\text {th }}$ to $5^{\text {th }}$ meeting : Teaching animals

$6^{\text {th }}$ to $7^{\text {th }}$ meeting $\quad:$ Teaching fruits

$8^{\text {th }}$ to $9^{\text {th }}$ meeting $\quad:$ Teaching things in the classroom

$10^{\text {th }}$ meeting : Giving post test

The learning process conducted in this study is by applying different strategies namely:

a. using teaching aids like flash cards, using video and giving student's worksheet made by the researchers

b. applying peer teaching that is giving the students chance to learn English alphabet in pairs with their peers

c. teachers as facilitator applied drilling technique when they find that their students have difficulty in spelling and memorizing the English alphabet

\section{FINDINGS}

This study is conducted aimed at finding strategies to teach alphabet for first graders of non-native English learners. The focus of this study is on the teaching alphabet since the students do not have English knowledge means that they never learn English before. The results of the study are as follows:

1. The student's profile. There are 56 students of first graders of SDN Brumbungan Kota Semarang, academic year of 2018/2019, on their $2^{\text {nd }}$ semester of the academic year. The age range is between 7 to 9 years old. The data of the student's profile is available below:

Tablel 1. Students' Profile 1A and 1B

\begin{tabular}{|l|l|l|l|l|l|}
\hline \multirow{2}{*}{ Class } & \multicolumn{5}{|c|}{ Number of students } \\
\cline { 2 - 7 } & \multicolumn{2}{|c|}{ Sex } & \multicolumn{4}{c|}{ Age } \\
\cline { 2 - 7 } & Male & Female & $\begin{array}{l}7 \text { years } \\
\text { old }\end{array}$ & $\begin{array}{l}8 \text { years } \\
\text { old }\end{array}$ & $\begin{array}{l}9 \text { years } \\
\text { old }\end{array}$ \\
\hline I A & 16 & 12 & 12 & 16 & 0 \\
\hline I B & 15 & 13 & 9 & 17 & 2 \\
\hline Total & $\mathbf{3 1}$ & $\mathbf{2 5}$ & $\mathbf{2 1}$ & $\mathbf{3 3}$ & $\mathbf{2}$ \\
\hline
\end{tabular}


2. The student's post-test. The researchers were conducted research for 10 times, 8 times for teaching alphabet with various topics and 1 time for pre-test and 1 time for post-test. The materials given are: Alphabet (26); Animals (10), Things in the classroom (10), and Fruits (10). Pre-test result shows that among 56 students, only 53 students who join the test and all of them can spell 3 English alphabet correctly for the letters B,O and P while for others are not. There are 36 students who cannot spell Y correctly. And the result of the post-test is as follows:

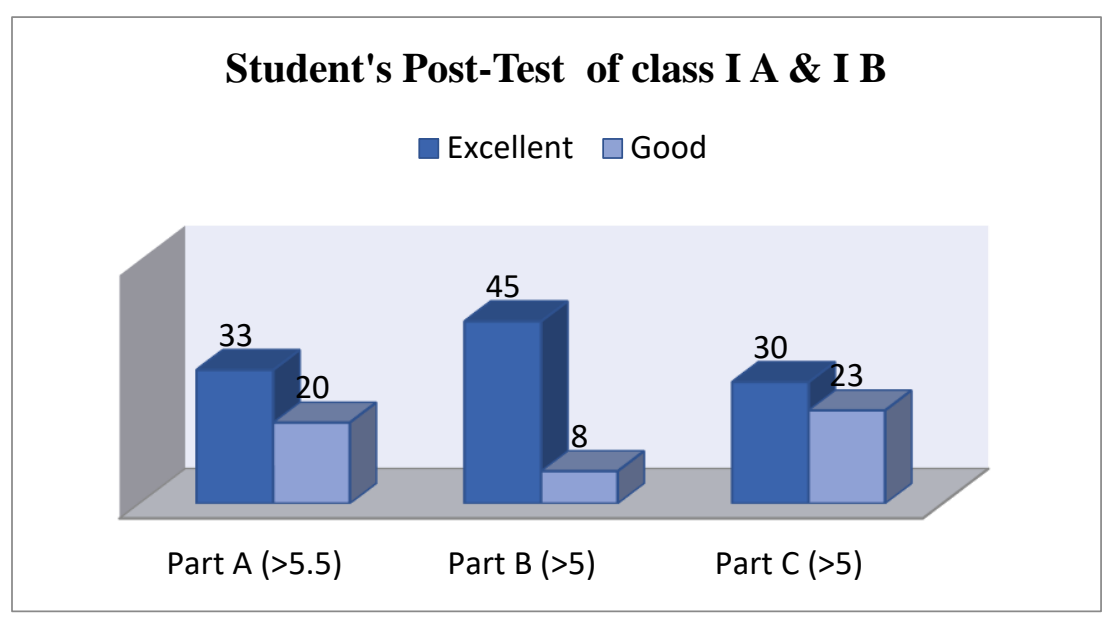

The post-test is divided into 3 categories namely: Part A (Missing Letter: Animals), Part B (Meaning: Fruits), dan Part C (Missing Letter: Things in the Classroom). The student's result shows that the number of students who can succeed in doing the test are: Part A 62\%, Part B 85\%, dan Part C 57\%. The study reveals that more than $50 \%$ of students who can do all the test so that the teaching alphabet in different topics is effective.

\section{CONCLUSION}

From the study, we can conclude that:

1. First graders are enthusiastic in learning English alphabet especially if the learning process using video, they can learn the alphabet through the song.

2. The teaching aids like flash cards is effective to help the first graders to visualize the English alphabet so that they can learn also how to pronounce and memorize the objects. 
3. Teachers for the first graders who are non-native English learners should know how to apply different strategies in teaching alphabet for them therefore the students will be motivated to learn English.

\section{REFERENCES}

Shaffer, David R \& Kipp, Katherine. 2010. Developmental Psychology: Childhood and Adolescence, eight edition. Wadsworth: Cengage Learning: USA

Octavia, Vinna and Widyaningrum, Agnes. Mengenal Kosa kata melalui TTES (Teamwork in Teaching English for Students). Prosiding SENDI_U 2019, ISBN 978-979-3649-99-3, pp $738-742$

Child Development Theories and Examples. By Kendra Cherry. https://www.verywellmind.com/child-development-theories-2795068)

The English Alphabet is Confusing (https://www.insightstoenglish.com/tips-insights/alphabet-is-confusing)

What Are Piaget's Stages of Development and How Are They Used? (https://www.healthline.com/health/piaget-stages-of-development)

Young children learn language naturally and unconsciously. Read our article to find out more about the factors that influence how young children learn English. (https://learnenglishkids.britishcouncil.org/helping-your-child/how-young-children-learnenglish-another-language) 